\title{
Çerkezköy Organize Sanayi Bölgesinde Bir Tekstil İşletmesinin En Uygun Kumaş Seçimi Probleminin Analitik Hiyerarşi Prosesi Yöntemi İle Analizi*
}

\author{
Analysis of the Most Appropriate Fabric Selection Problem of a Textile Company in Çerkezköy Industrial Zone \\ by Analytical Hierarchy Process Method \\ Erkan Arı, ${ }^{\text {a,** }}$ Ebru Aydın ${ }^{\mathrm{b}}$ \\ a Doç. Dr., Kütahya Dumlupınar Üniversitesi, İktisadi İdari Bilimler Fakültesi, Ekonometri Bölümü, 43000, Kütahya/Türkiye. \\ ORCID: 0000-0002-8942-7590 \\ bBilim Uzmanı, Çerkezköy, 59500, Tekirdağ, Türkiye. \\ ORCID: 000-0002-5897-6220
}

\section{MAKALE BİLGİSI}

\section{Makale Geçmişi:}

Başvuru tarihi: 06 Şubat 2019

Düzeltme tarihi: 10 Mayıs 2019

Kabul tarihi: 16 Mayıs 2019

\section{Anahtar Kelimeler:}

Analitik Hiyerarşi Prosesi (AHP)

Karar Vericiler

Tekstil ve Kumaş Seçimi

\section{ARTICLE INFO}

\section{Article history:}

Received 06 February 2019

Received in revised form 10 May 2019

Accepted 16 May 2019

\section{Keywords:}

AnalyticalHierarchyProcess (AHP)

DecisionMakers

Textile and FabricSelection

\section{ÖZ}

İşletmeler, üretim sürecinde karar verirken birçok faktör rol oynamaktadır. Çalışmada, tekstil sektöründe kumaş üretimi yapan birişletmenin en uygun kumaş seçimi Analitik Hiyerarşi Prosesi ile analiz edilmiştir. Firmanın yoğun olarak ürettiği 4 çeşit kumaş ele alınmıştır. Bu kumaşlar içerisinden karara etki eden kriter ve alt kriterler belirlenmiştir. Analizde 5 çeşit kriter ele alınmış ve bu kriterler de kendi içlerinde alt kriterlere ayrılmıştır. Karar verici olarak, üretimde karar vermeye yetkisi bulunan bir ekip ile değerlemeler yapılmıştır. Kriter ve alt kriterlere Expert Choice programı ile ikili karşılaştırmalar yapılmış ve karar vericiler aracılığı ile değer verilerek analiz sonuçlarına ulaşılmıştır-

\section{Giriş}

Tekstil Sektörünün genişlemesi ile birlikte toplumda rekabet artmış ve toplum farklı tür de kumaşlara ve ürünlere yönelmiştir. $\mathrm{Bu}$ durum beraberinde firmaların farklı türde ürün çeşitlerine yol açmıştır. Firmalar ürünleri üretirken birçok kıstas söz konusudur. Ürünün firmaya maliyeti, Pazar imkanı, tüketici tercihleri gibi bir çok faktör firmaların üretim süreçlerine etki etmektedir. Bu durumda

\begin{abstract}
A B S T R A C T
Many factors play a role in the decision-making enterprises. In the study, the most suitable fabric selection of a fabric manufacturing company in the textile sector was analyzed by The Analytical Hierarchy Process. Four types of fabrics produced by the company are covered. The criteria and sub-criteria affecting the decision were determined within these fabrics. In the analysis, 5 criterias are considered and these criterias are divided into sub-criteria. As a decision-maker, valuations were made with a team authorized to make decisions in production. The criteria and sub- criteria were compared with Expert Choice program and the results were obtained by input valuation of decision makers
\end{abstract}

\footnotetext{
*Bu çalışma, 2019 yılında Doç. Dr. Erkan Arı’nın danışmanlığında yürütülen Kütahya Dumlupınar Üniversitesi Sosyal Bilimler Enstitüsü yüksek lisans öğrencisi Ebru Aydın'ın "Çerkez Organize Sanayi Bölgesinde Tekstil İşletmesinin Üretiminde En Uygun Kumaş Seçimi Probleminin Analitik Hiyerarşi Prosesi Yöntemi İle Analizi” başlıklı tez çalışmasından üretilmiştir

** Sorumlu yazar/Corresponding author.

e-posta: erkan.ari@dpu.edu.tr
} 
diğer ülkelere de yayılmıştır. Sanayileşmenin ilk başladığı süreç tekstil sektörüdür (Gemci, 2007:10).

Tekstil sektörü geniş kapsamlı üretim kapasitesine sahiptir. Tekstil sektöründe; elyaf, iplik, örme, dokuma, keçe, tufting yüzeylerin olduğu dokusuz yüzeyler, ev tekstili ürünleri, ip, koruyucu bant, halılar ve bunun gibi birçok ürünler yer almaktadır. Örme ve dokuma kumaştan üretilen giyim ürünleri ise hazır giyim sektöründe yer almaktadır. $\mathrm{Bu}$ sektör genel anlamı ile emek yoğunluk çalışan bir sektördür. Tekstil sektöründe üretilen ürünler modaya yönelik işlenen katma değer yaratan ve ayrıca emek yoğun bir sektör olduğundan genelde işçiliğin ucuz olduğu, gelişmekte olan ülkelerin yatırım yapmayı tercih ettiği sektördür (Ekti, 2013:6).

Ülkemiz de hazır giyim sektörü emek yoğun çalışılan bir sektördür ve ülke ekonomisine faydası oldukça fazladır. Bu sektörde teknolojik gelişmelere pek rastlanmaz. Hazır giyim sektörü ihracat ağırlıklı bir sektördür ve tekstil içerisinde en büyük paya sahiptir. Bu sektörün ekonomiye katkısının yanı sıra işgücü alanında birçok kişiye istihdam sağladığı ve diğer sektörlerin de gelişimlerine katkıda bulunduğunu söylenebilir. Türkiye'de bu sektörde önemli bir paya sahiptir (Gemci, 2007: 15).

Kumaşlar kendi içlerinde örme, dokuma ve dokusuz kumaş olarak 3 bölümde incelenebilir. Dokuma kumaşlar, iplikler mekik içindeki bir çubuk üzerine sarılıdır. Zincir belirli aralıklarda ipliklerin yerini değiştirip iplikleri birbirlerinden uzaklaştıklarında, dokumacı açılan kanala bir kenarından diğer kenarına mekiği geçirir. Daha sonra iplikler tersi yönde birbirinden uzaklaşır. Dokumacı yeniden mekiği bir uçtan diğer kenara kadar geçirir. $\mathrm{Bu}$ şekilde üretilen bir kumaş çeşididir. Her mevsim koşuluna uygun kumaşlar üretilir. Örgü kumaşlara kıyasla daha az nemçeker. Örme kumaşlar, ipliklerin iğne yardımı ile belli düzen çerçevesinde birbirinin içinden geçirilmesi ile elde edilen örme türü bir kumaştır. İplikler iğne yardımı ile ilmek haline getirilerek esnek bir yüzey elde edilir. Ene ve boya esneyebilme özelliğine sahiptirler. Dokusuz Kumaşlar; parçalı liflerden oluşan ısı ve mekanik işlemler aracılığı ile bir araya getirilen kumaş çeşididir. En az maliyetle en hızlı üretilen bir kumaştır. Bunun yanı sıra kumaşlar viskon ve polyester olarak da ayrılmaktadır. Viskon kumaşlar pamuk kumaş özelliklerine daha yakın kumaşlardır. Doğal bir kumaştır. Yumuşak rahat bir kumaş türüdür. Polyester kumaşın tercih sebebi maddeler halinde sıralanabilir: (Özek, 2014: 13-14).

- Parlak, sağlam, esnek ve kaygan yapıya sahiptir.

- Polyester 1şığa dayanıklı bir kumaş türüdür.

- Kolayca kuruma özelliğine sahiptir bundan dolayı dış giyimde oldukça yoğun tercih edilir.

- Kırışmadığından pek ütü istemez bu yüzden de tercih sebebidir.

- Yumuşak ve ipeksi bir dokusu vardır.

- Kuru temizleme yapmadan kolayca makinada yıkanabilir.

- Leke tutmaz, rengi yıkama solma yapmaz.

- Eşofman ve benzeri ürünler diz yapmasından dolayı şikayetler olur bu durum polyester kumaşlarda olmaz.

- Böceklerden etkilenmez, küf ve mantar gibi mikroorganizmalardan zarar görmez.
- Pamuk ve ipek kumaşlara yani doğal kumaşlara kıyasla daha ucuzdur.

Ayrıca kumaşlara baskı, boyama ve bunun gibi işlemler uygulanmaktadır. Bu durum düz boya, dijital bask1 ve rotasyon baskı olarak 3 bölümde incelenebilir. Düz boya; kumaşa renk verme işlemidir. Çektirme yöntemi ve emdirme yöntemi yolu ile kumaşlara renklendirme yapılmaktadır. Çektirme yöntemi ürünün düzgün bir şekilde boyanmasına imkan sağlamaktadır. Emdirme yöntemi ise avantajlı olması sebebi ile en çok tercih edilen yöntemdir. Rotasyon bask1; metresi uzun olan kumaşlarda kullanılan avantajlı yöntemdir. Basılacak kumaş bant üzerine serilir sürekli dönen silindir altından geçerek kumaşa renk verdirme işlemi yapılır. Yatırım maliyeti bakımından en pahalı tekniktir. Dijital Baskı; baskının bilgisayar destekli ortamda yapılması işlemidir. Görseller bilgisayar ortamında hazırlanır. Hemen her sektör Dijital baskıyı kullanır. Dükkan vitrini, mağaza, bina cepheleri, 1şıklı-1şıksız tabela ve daha birçok ürün dijital baskı uygulamalıdır (Çakıroğlu, 2015: 89).

Bu çalışmada, Çerkezköy'de tekstil sektöründe faaliyet gösteren firmada üretimde en uygun kumaş seçimi problemi analiz edilmiştir. Çalışmada analiz ExpertChoice paket programı yardımıyla AHP yöntemi ile yapılmıştır. Çalışmanın amacı; tekstil firması ve müşteri potansiyeli bakımından en uygun kumaşı belirlemek, firmaya katkı sağlayan kumaş çeşidinin üretimi boyunca katkı sağlayacak çalışmalar yapmaktır. Ayrıca elde edilen sonuçlar doğrultusunda firmanın izlediği üretim politikası, ne yönde bir çalışma aşaması izliyor bununla ilgili rakip firmalar ya da ortalık yapacak firmalar veya müşterilere bilgi imkanı sağlamaktır.

\section{Literatür İncelemesi}

Literatür incelendiğinde, Analitik Hiyerarşi Prosesi (AHP) nin pazarlama, finans, eğitim, kamu politikaları, ekonomi, tıp, spor ve benzeri alanlarda çok sayıda araştırmada kullanıldığ1 tespit edilmiştir (Kuruüzüm ve Atsan, 2001:84). AHP yöntemi ile tekstil alanında yapılmış araştırmalara da rastlamak mümkündür.

Güner (2003), “Analitik Hiyerarşi Yönteminin Fason İşletme Seçiminde Kullanılması" isimli çalışmasında firmanın fason seçiminde AHP yöntemi kullanarak fasoncu seçim problemine çözüm aramıştır. Çalışmada amaç, firma için en doğru fason üreticiyiseçmektir. Bunun için ilk olarak probleme ait hiyerarşik yapı kurulmuş, amaç belirlenmiş ve amaca katkısı olacak kriterler oluşturulmuştur. Güven, kalite tutturma, temin tutturma, fiyatın uygun olması ve makine parkuru olarak 5 tane kriter belirlenmiştir. Daha sonra fason için 4 alternatif belirlenmiş ve her bir kriter ikili olarak karşılaştırmalara tabi tutularak göreli önem dereceleri belirlenmiştir. Analiz sonuçlarında, A firmasının en uygun fiyatı vermesine rağmen güvenemniyet konusunda en kötü firma olduğu görülmüştür. Her bir kriter için farklı firmalar ilk sıraları almıştır.

Tong vd. (2012), Çin'de, tekstil baskı işletmesinde büyük miktarda su tüketen ve çok sayıda kirleticiyi boşaltan büyük bir sorun olduğunu ve fabrikanın bir su koruma ve atık azaltıcı temizleyici üretim değerlendirme sisteminden yoksun olduğunu belirlemiştir. Bu sorunun çözümü için, AHP ile tekstil baskı endüstrisinde su koruma ve atık azaltıcı temizleyici üretim gösterge sisteminin kurulması 
önerilmiştir. Çalışmada, karar matrisi Delphi Yöntemi ile ortaya konmuştur. Son olarak, Yaahp yazılımıla her göstergenin ağırlığı elde edilmiştir. Çalışma sonucunda, su kaynağından tasarruf etmenin ve atık emisyonunu azaltmanın etkili bir yolu olarak daha temiz üretim tekniği entegrasyonu önerilmiştir.

Banwet ve Majumdar (2012), Hindistan'da tekstil endüstrilerinin çoğu pamuk tabanlı olduğundan pamuğun kalite değerini belirlemeyi amaçlamıştır. Bu amaçla, pamuk kalitesini etkileyen pamuk lifi, mukavemet, uzama, incelik, uzunluk, kısa elyaf içeriği vb. gibi faktörler AHP -TOPSIS yaklaşımı kullanılarak belirlenmeye çalışılmıştır. Çalışmada, pamuk lifleri, pamuğun kalite değerinin belirlenmesi için AHP-TOPSIS ve GA-TOPSIS yaklaşımlarına göre derecelendirilip seçilmiştir. AHPTOPSIS yaklaşımında, AHP, çeşitli pamuk lifi özelliklerinin (karar kriterleri) ağırlıklarını ortaya çıkarmak için kullanılmıştır. TOPSIS, yakınlık endeksi değerine göre çeşitli alternatifleri sıralamak için uygulanmıştır. GATOPSIS yaklaşımında ise pamuk lifi özelliklerinin ağırlıkları (karar kriterleri) genetik algoritma ile belirlenmiştir. Uygunluk fonksiyonu olarak pamuk lifi kalitesi ile iplik mukavemeti arasındaki korelasyon katsayısı alınmıştır. Son olarak, iki yaklaşımın etkinlikleri arasında karşılaştırmalı bir analiz yapılmıştır.

Sasil ve Digalwar (2015) "Application of AHP and TOPSIS MethodforSupplierSelectionBetweenIndia\&China in TextileIndustry" adlı çalışmada, Tekstil üretiminde Dünyada ilk 2 sırayı alan Çin ve Hindistan'da en iyi tedarikçileri seçmek için, somut ve maddi olmayan faktörler arasında bir denge oluşturmayı amaçlamıştır. Bu amaçla, tedarik zinciri döngüsündeki tedarikçi seçim sürecini etkileyen ürün kalitesi, hizmet kalitesi, teslim süresi ve fiyat gibi bazı önemli kriterler göz önüne alınmıştır. Çalışmada, Analitik Hiyerarşi Prosesi'ne (AHP) dayanarak her bir kriter için ağırlıklar hesaplamış ve tedarikçileri sıralamak için bu ağırlıklar TOPSIS yöntemine girilmiştir.

Başkaya ve Akar (2005), Analitik Hiyerarşi Prosesini kullanarak tekstil işletmesinin ham kumaş, boyalı kumaş ve perdelik kumaş alternatifleri arasından hangisini üretmesi gerektiğine karar vermeye çalışmıştır. Çalışmada, karara etki edecek kriter ve alternatifler firma yöneticileri belirlenmiştir. Bunun için, karlılık, satılabilirlik, verimlilik ve hammadde temini olarak 4 kriter belirlenmiştir. Bu kriterlere ait sübjektif yargılar karar vericiler yardımı ile belirlenmiş ve ikili karşılaştırma matrislerine tabi tutulmuştur. Çalışmada, firma için en uygun perdelik kumaş üretilmesi sonucuna varılmıştır.

Güleş, vd. (2014), "Hazır Giyim sektöründe Tedarikçi Seçimi” başlıklı çalışmada hazır giyim sektöründe tedarikçi seçimi problemini araştırmıştır. Konya ilinde faaliyet gösteren tekstil işletmesinde tedarikçi seçimi AHP yöntemi ile analiz edilmiştir. Çalışmada esneklik, teslim, maliyet, kalite ve güvenilirlik gibi 5 adet kriter ele alınmıştır. Bu kriterlere ait 20 adet alt kriter belirlenmiştir. Her bir kriter ve alt kriter birbiri ile ikili karşılaştırmalara tabi tutulmuştur. Elde edilen sonuçlara göre en önemli kriter maliyet kriteri olarak belirlenmiş ve alternatifler arasından ise $\mathrm{C}$ alternatifi ; teslim, maliyet ve güvenilirlik ana kriterlerine göre en iyi alternatif olduğundan firma için en uygun tedarikçi $\mathrm{C}$ tedarikçisi olmuştur.

Aydın, (2006) tarafından Türk ev tekstili sektöründe tutundurma karması elamanlarının belirlenmesi probleminin çözümü, AHP uygulanarak analiz edilmiştir. Çalışmada kriter, alt kriter ve alternatiflerin belirlenmesinde, pazarlama bölümünde görevli ve alanında uzman öğrenci ve yöneticilerden oluşan bir ekipten yararlanılmıştır. Pazar payı yüksek 7 firmanın yöneticilerinin görüşleri ile veriler elde edilmiştir. Çalışma sonucunda, yüksek pazar payına sahip 7 firma için en uygun tutundurma karması elemanı kişisel satış olarak belirlenmiştir. Kişisel satışlardan sonra en önemli ikinci alternatif ise reklam kriteri olarak belirlenmiştir. Analiz sonucuna göre en önemli kriterin kişisel satış çıkmasında, ev tekstili ürünlerinin özelliklerinden ve tüketici kitlesinin bayanlardan oluşmasından kaynaklandığı ifade edilmiştir.

Yılmaz, (2015) “Türkiye'de Tekstil sektöründe Dağıtım kanalı seçiminde karşılaşılan problemler ve Adıyaman'da Tekstil firmaları üzerine bir uygulama" adlı çalışmasında dağıtım kanalı sisteminde işletmelerin karşı karşıya kaldığı problemleri araştırmıştır. Çalışmada, pazar yapısı, rekabet, ürün özellikleri, tüketici tercihleri gibi birçok faktörlerin dağıtım kanallarına etkileri incelenmiştir.

Y1lankıran, " (2006) "Investigation of thenonwovenfabricproductiontechnologiesand a costbenefitanalysisfortheusage of medicaltextiles" başlıklı çalışmada, Swot ve Portföy analizleri kullanılarak bir işletme stratejisi geliştirilmeyi amaçlanmıştır. Çalışmada AHP yitemel alan çok kriterli bir karar destek modeli oluşturulmuş ve bebek bezi imalatı için kuruluş yeri seçimi yapılmıştır. Seçilecek yer fayda/ maliyet analizi ve grup karar verme mekanizması ile elde edilmiştir. Satış miktarı ve fiyatı üzerindeki değişikliklerin gelir tablosuna nasıl yansıyacağı duyarlılık analizi ile test edilmiştir. Çalışma sonucunda \%2'lik büyüme oranı olan tek kullanımlık bebek bezi imalatı yatırımının uygulanabilir ve karlı bir iş olduğu sonucuna varılmıştır.

\section{Yöntem}

Bir karar verme sürecinde birden fazla kriter ve amaç olması durumu, çok kriterli karar verme problemleri adı altında incelenmektedir. Çok Kriterli Karar Verme (ÇKKV); Çok Amaçlı Karar Verme (ÇAKV) ve Çok Nitelikli Karar Verme (ÇNKV) olmak üzere 2 bölümde incelenmektedir. Çalışmada, çok nitelikli karar verme yöntemi olan AHP analizi ile uygulama yapılmıştır.

\subsection{Analitik Hiyerarşi Prosesi (AHP)}

AHP ilk olarak 1968 yılında Myers Ve Alpert ikilisi tarafından ortaya atılmış ve 1977 'de ise Profesör Thomas LorieSaaty tarafından geliştirilerek karar verme problemlerin çözümünde kullanılır hale gelmiştir (Yaralığlu, 2001). Analitik Hiyerarşi Prosesi (AHP), karar problemlerinde karar alternatif ve kriterlerine göreceli önem değerleri vermek suretiyle yönetsel karar mekanizmasının çalıştırılması esasına dayanan bir karar verme işlemidir. Karar vericinin hedefine ilişkin amaç doğrultusunda, kriter, alt kriter ve seçenekler arasındaki sistematik ilişkiyi ortaya koyar.AHP yönteminin de her yöntemin gibiüstün ve ve zayıf tarafları vardır. 
AHP 'nin üstün yanları şu şekilde sıralanabilir (Timör, 2011):

$>$ Büyük ölçekli problemleri ele alabilmesi özelliği ile esnek bir modelleme aracıdır. Her türlü kurumsal ve kişisel probleme çözüme kavuşturma da etkilidir.

$>$ Kriterler ikili olarak her düzeyde karşılaştırılabilmektedir. Çok daha fazla sayıda kriter probleme dahil edilebilmektedir.

> Karmaş1k problemleri basit hale getirir.

> Nitel ve nicel kriterleri birlikte ele alma imkânı sunar.

$>$ İleri seviyede teknik bilgi gerektirmemekte ve neredeyse herkes tarafindan kullanılmaktadır.

> Grup kararlarında kullanıma uygundur.

$>$ Grup halinde karar verirken düşünceye ait zıtlıklar da dikkate alınır. $\mathrm{Bu}$ durum sonuçların güvenilirliğini arttırır.

> Problemdeki başarı karar vericinin tercihlerini ifade etme yeteneği ile ilgilidir. İkili karşılaştırmalara bağlı olarak daha fazla bilgi verir. Sadece ölçülebilen değerleri değil aynı zamanda ölçülemeyen faktör ve amaçların da dikkate alınmasına olanak sağlar.

AHP 'nin zayıf yanları ise şu şekilde sıralanabilir: (Aky1ld1z, 2006).

> AHP'de kesinlikle doğru kararlar bulunamaz. Doğruya yakın veya daha iyi karar vermeyi, fikir birliğine varılmasını sağlar. Karar vericilerin yargıları ile yönetildiğinden ortaya çıkan sonucu doğrulamanın bir yolu bulunmadığı ifade edilir.

> AHP yönteminde modelin oluşturulmasında faktörlerin her kademede doğru kullanılamaması, seçilmemesi ve bulguların sorgulanamaması sonuçların geçerlilikten uzaklaşmasına sebep olabilir. Karşılaştırmalar da ayrıntılı ve tam bilgi kullanıldığında en iyi sonuca ulaşılır.

$>$ Kademe sayısının artması durumunda ikili karşılaştırma matrisleri de artar. AHP modeli kurmak daha fazla zaman ve çaba ister.

$>$ Sira değiştirme, herhangi bir karar seçeneği probleme eklendiğinde veya çıkarıldığında karar seçenekleri sıralamasının değişmesi demektir. Problemde yer alan seçenekler ve veya kriterlerin ağrılıklarının değişmesi sebep olur.

$>$ Kriterlerin seçenekler dikkate almadan değerlendirilmesi sorun yaratır. Ayrı sözel ve sayısal yöntemler farklı kararların alınmasına sebep olur.

AHP'de ilk adım hiyerarşik yapının kurulmasıdır. Hiyerarşi Kavramı; Hiyerarşi; basamak, sıra, derece düzeni anlamına gelir. Hiyerarşi kurulurken şu hususlara dikkat edilir: (Yetim, 2004:139).

-Problem en iyi şekilde temsil edilir.
-Problemi etkileyen tüm yan faktörler göz önüne alınır.. -Çözümü etkileyecek tüm yayın ve belgeler dikkate alınır. -Problemde etkili olacak karar vericiler belirlenir.

Hiyerarşik yapı kurulduktan sonra aşağıdaki adımlar uygulanır:

- İşlemleri gerçekleştirmek için öncelikle bir "Karşılaştırma matrisi”" oluşturulur.

- Elde edilen bu matris daha sonra bir "öncelikler vektörüne" dönüștürülür.

- “Uyum oranı" hesaplanır (Timor, 2011: 32).

Hiyerarşik yapıda model kurulurken kıstas ve alternatifler oluşmaktadır. Hiyerarşik model aşağıda gösterilmiştir.

Şekil 1. Hiyerarşik Yap1 Modeli

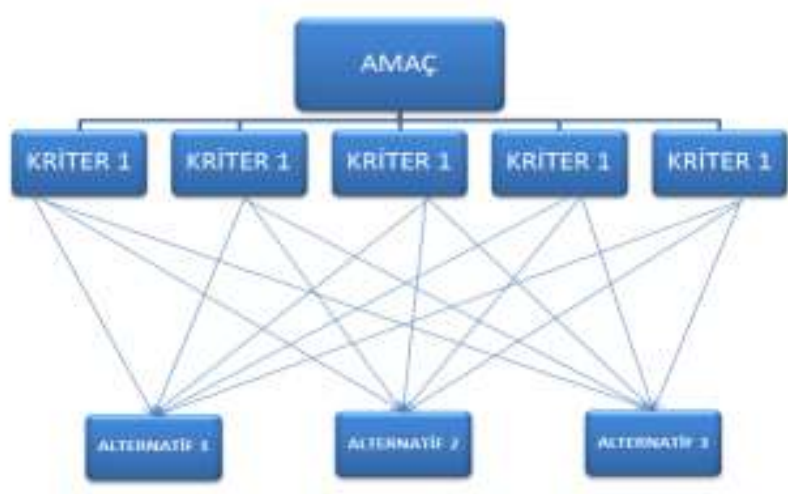

Kaynak:(Timör, 2011)

Analitik Hiyerarşi Prosesi ile karar aşamaları genel olarak verilmiştir (Saaty, 1982:6).

Aşama 1: Modelin kurulması ve problemin formüle edilmesi: Karar sürecini etkileyen tüm faktörler anket yolu ile ya da uzman görüşü yardımı ile belirlenir. Bilgiler sonucunda karara etki eden kriter ve alt kriterler belirlenerek hiyerarşik yapı kurulur.

Aşama 2: İkili karşılaştırmalar matrisinin oluşturulması: Saaty tarafından oluşturulan karşılaştırmalar ölçeği kullanılarak ikili karşılaştırmalar matrisi kurulur. Karşılaştırmalar ölçeği Tablo 1'de verilmiştir.

Tablo 1. Karşılaştırma Ölçeği

\begin{tabular}{|c|c|c|}
\hline $\begin{array}{c}\text { ÖNEM } \\
\text { DERECESİ }\end{array}$ & TANIM & AÇIKLAMA \\
\hline 1 & $\begin{array}{l}\text { Eşit Derecede } \\
\text { Önemli }\end{array}$ & $\begin{array}{c}\text { Her iki faktör aynı öneme } \\
\text { sahip. }\end{array}$ \\
\hline 3 & $\begin{array}{l}\text { Orta Derecede } \\
\text { Önemli }\end{array}$ & $\begin{array}{c}\text { Tecrübe ve yargilara göre } \\
\text { bir faktör diğerine göre } \\
\text { biraz daha önemli }\end{array}$ \\
\hline 5 & $\begin{array}{c}\text { Kuvvetli } \\
\text { Derecede } \\
\text { Önemli }\end{array}$ & $\begin{array}{l}\text { Bir faktör diğerinden } \\
\text { kuvvetle daha önemli }\end{array}$ \\
\hline 7 & $\begin{array}{l}\text { Çok Kuvvetli } \\
\text { Derecede } \\
\text { Önemli } \\
\text { Mutlak }\end{array}$ & $\begin{array}{l}\text { Bir faktör diğerine göre } \\
\text { yüksek derecede kuvvetle } \\
\text { tercih edilir. } \\
\text { Faktörlerden biri }\end{array}$ \\
\hline 9 & $\begin{array}{l}\text { Derecede } \\
\text { Önemli }\end{array}$ & $\begin{array}{l}\text { diğerinden çok yüksek } \\
\text { derecede önemlidir. }\end{array}$ \\
\hline $2,4,6,8$ & $\begin{array}{l}\text { Ara Degerli } \\
\text { Temsil eder }\end{array}$ & $\begin{array}{l}\text { Iki faktör arasındaki } \\
\text { tercihte küçük farklar } \\
\text { olduğunda kullanılır. }\end{array}$ \\
\hline
\end{tabular}


Kaynak:(Özdemir ve Saaty,2006)

Aşama 3: Kriter ağırlıklarının ve alternatiflerinin belirlenmesi: Her karar alternatiflerinin ağırlığı hesaplanmaktadır. Amaç, elemanların her birinin amaca ne kadar yardımının olacağının belirlenmesidir. Matematiksel hesaplamalar sonucu matrislerin en büyük öz değere karşılık gelen öz vektör bulunur. Özdeğer ve özvektörlerin öncelik sıraları ve göreceli önemleri belirlenir.

Aşama 4: Tutarlılık oranının hesaplanması: İkili karşılaştırmalardan sonra nihai kararın doğruluğu, kalitesi, geçerliği ve güvenilirliğini denetlemek için tutarllık oranının hesaplanması önemlidir. Karar vericilerin kriterler arasında karșılaştırmaları yaparken tutarlı olup olmadığını görmek için her bir matris için Tutarlılık Oranı (TO) bulunur. Bulunan oranın 0,10 'dan veya daha düşük olması yeterlidir (Aytürk, 2006). Tutarlılık oranı Eşitlik 1'de ifade edilmiştir.

$\mathrm{T} . \mathrm{O}=\frac{\lambda \max -n}{n-1}$

Karşılaştırma ölçeğinde üst sınır 9 olarak belirlenmiștir. Bunun nedeni şu şekilde ifade edilebilir (Dağdeviren, 2002: $55)$.

- Nitelik olarak farklılıklar pratikte anlamlı olup karşılaștırma yapılan sayıların aynı büyüklük sırasından gelmesi ya da kullanılan özelliklerin yakın olması yapılan çalışmanın doğruluğunu arttırmaktadır.

- Niteleyici ayrımlar yapma imkânı, eşit, zayıf, güçlü, çok güçlü ve tam olarak 5 sifatla sağlanmıştır. Ara değerler ile birlikte 9 tanımlayıcı elde edilmiştir.

- Rakamları değerlendirmek için çoğu kez kullanılan pratik yöntem 3 kategoride; yüksek, orta ve düşük seviye olarak sınıflandırılır. Daha detaylı sınıflandırma için bu kategorideki her biri tekrar kendi içinde yüksek, orta ve düşük olarak sınıflamaya tabi olur. Kısacası, anlam farklılıkları her zaman 9 türde ifade edilir. Bundan dolayı 9 rakamının üzerine çıkılmamalıdır.

Anında yapılan karşılaştırmalar da $7 \pm 2$ tane maddenin psikolojik limiti şunu önerir; eğer birinci sebepte verilen tarife uygun $7 \pm 2$ tane madde ele alınırsa ve bunların hepsi birbirinden çok az farklı ise, bu farklılıkların gösterilebilmesi için dokuz noktaya ihtiyaç duyulur. Bir kişi aynı anda $7 \pm 2$ durumunu değerlendirebilmektedir.

\section{Uygulama}

Çalışma, Çerkezköy Organize Sanayi bölgesinde faaliyet gösteren bir tekstil firması ele alınarak yapılmıştır. Çalışmada, hangi kumaşın üretilip satılmasının firma açısından daha iyi olacağına karar verebilmek için karar mekanizmaları ile birlikte Analitik Hiyerarşi Prosesi analizine başvurulmuştur. Analiz yapılırken karar probleminin çözümünde konuyla ilgili bölüm yöneticilerinden yardım alınmıştır. Üretim müdürü, planlama müdürü, finans müdürü, işletme müdürü ve işletme çalışanı olmak üzere 5 kişilik ekip yardımı ile karar mekanizması kurulmuştur. Çalışmada, en uygun kumaşın seçiminde 5 kriter, 16 alt kriter, 4 alternatif kumaş kullanılmıştır. Seçenek ve kriterlerbelirlendikten sonra hiyerarşik yapı kurulmuştur. Hiyerarşik yapıda amaç en uygun kumaş üretimidir. Hiyerarşik yapı Şekil 2'de gösterilmiş̧tir.

Şekil 2. En Uygun Kumaş Seçimi İçin Hiyerarşik Yapı

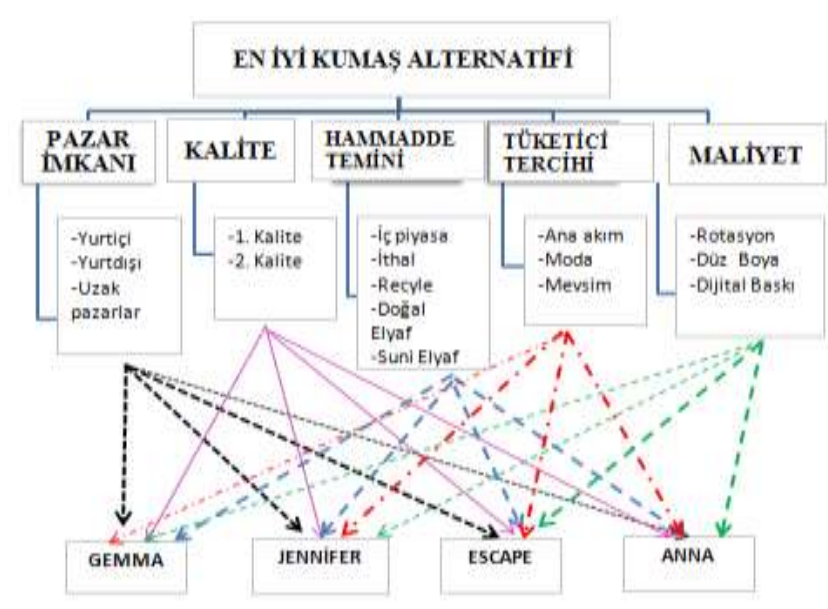

Çalışma ekibine Tablo 1'de yer alan karşılaştırma yapılırken kullanılan önem dereceleri anlatılmıştır.

Çalışmada, firmanın yoğun olarak üretimini yaptığı 4 farklı özellikte kumaş çeşidi ele alınmıștır. Kumaşlar; Gemma, Jennifer, Escape ve Anna olarak adlandırılmaktadır. Firma ihracar ağırlıklı çalıştığı için kumaş isimleri yabancı kökenlidir. Ele alınan bu kumaşlar firma açısından üretim kolaylığı ve karlılık bakımından analiz edilmiştir. Analiz yapılırken; pazar imkanı, kalite, hammadde temini, tüketici tercihleri ve maliyet olmak üzere 5 kriter belirlenmiștir. Bu kriterlere ait alt kriterler belirlenmiş ve bu kriterler ikili karşılaşıırmalara tabi tutulmuştur. Karşılaş̧ırmalar ExpertChoice programı ile analiz edilmiştir.

Çalışmada karar problemi tekstil firması açısından en uygun kumaş üretimidir. Daha sonrasında kriterler, alt kriterler ve alternatifler belirlenmiştir. Tüm veriler elde edildikten sonra ikili karşılaş̧ırmalar yapılarak firma için en uygun kumaş seçilmiş ve analizi edilmiştir. Çıkan analiz sonuçları karar vericiler ile değerlendirilerek sonuçların anlamlı olup olmadığ 1 test edilmiştir. Kriterlerin ve alt kriterlerin kendi içlerinde program yardımı ile ikili karşılaştırma tabloları oluşturularak karar vericilerin fikirleri doğrultusunda değer verme işlemi yapılmış ve sonuçların tutarlılı̆̆ı test edilmiştir.

Karşılaştırmalar arasında tutarlılığın ölçümünü gösteren oran uyum oranıdır. Uyum oranı 0,1 den küçük olması sonuçların tutarlı olduğunu göstermektedir. Kriter ve alt kriterler karşılaş̧ırma sonuçları kontrol edilerek 0,1 den büyük olanlar için tekrardan değerlendirmeler yapılarak her bir kriterin tutarlı olması hedeflenmiş̧tir.

Çalışmada, öncelikle Ana kriter olarak belirlenen 5 kritere kendi içlerinde karşılaştırma yapılmıştır. Karşılaştırmaya ait ağırlık ve önem dereceleri Şekil 3'de gösterilmiştir. 
Şekil 3. Ana Kriterlere Ait Ağırlık ve Önem Dereceleri

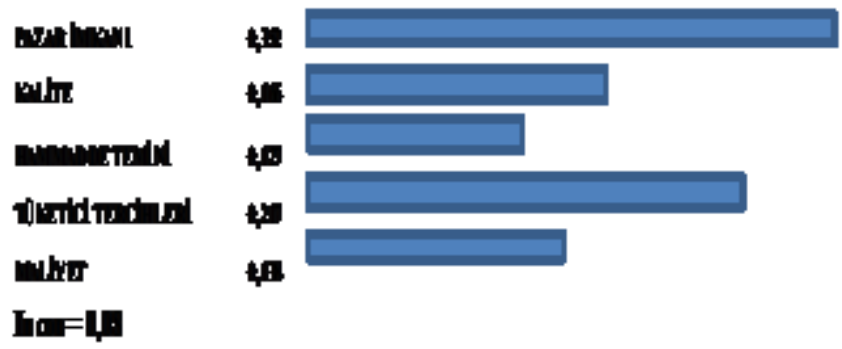

Şekil 3 incelendiğinde firmanın üretim sürecinde pazar imkanı kriterinin önemli rol oynadığı görülmektedir. Yani firma üretim yaparken üreteceği kumaşın pazarı olup olmadığına önem vermektedir. İkinci sırada ise firmanın tüketici tercihleri kriterinin önemli olduğu görülmektedir. Her aşamada; ana kriterlere ait alt kriterler kendi aralarında karşılaştırmalara tabi tutulmuştur. Karşılaştırmalar sonucunda her bir kriterin tutarlılık oranları kontrol edilmiştir. Benzer işlemler her bir alt kriter için uygulanmıștır.

Hiyerarşik yapıda her bir kriterlerin karşılaştırılmasından sonra, alternatiflerin bu kriterleri ne derecede taşıdıklarına bakarak en uygun kumaş türü seçilmiştir. Burada alternatifler her bir alt kriter ilgili kriterleri taşıma dereceleri dikkate alınarak karşılaştırılmıştır. Herbir alt kriter belirlenen 4 çeşit kumaş ile kıyaslamaya tabi tutulmuştur. Önem dereceleri ve tutarsızlık oranları kontrol edilmiştir. Kıyaslamalar yapıldıktan sonra programdan hedefe göre kumaşa ait öncelik belirlenmiştir. Birçok kriter açısından üstün durumda olan Jennifer adlı kumaş üretilmesi en uygun kumaş türü olarak elde edilmiştir. Devamında ise Escape adlı kumaşın önem derecesi 2. sırada yer almıştır. Kumaşlara ait öncelik değerleri Şekil 4'de verilmiştir.

Şekil 4. Kumaşlara Ait Öncelik Değerleri

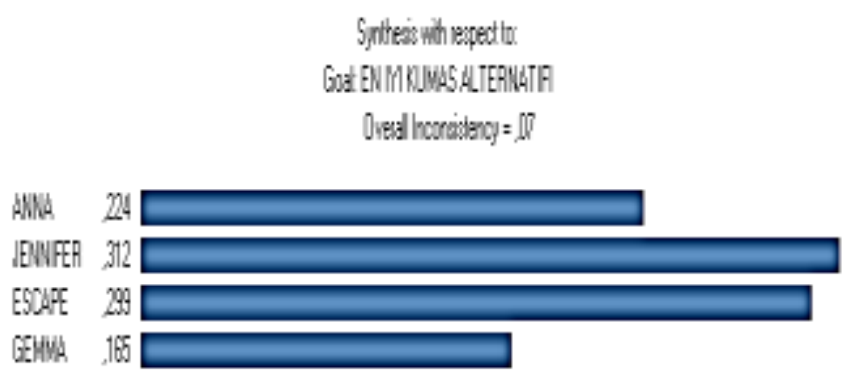

AHP, sübjektif yargıları da içerdiğinden ortaya çıkan sonucun kriterlerde meydana gelen değişime karşı duyarlılığını incelemek için probleme duyarlılık analizi uygulanmıştır. Duyarlılık Analizi sonucu Şekil 5'de gösterilmiştir.
Şekil 5. Duyarlılık Analizi
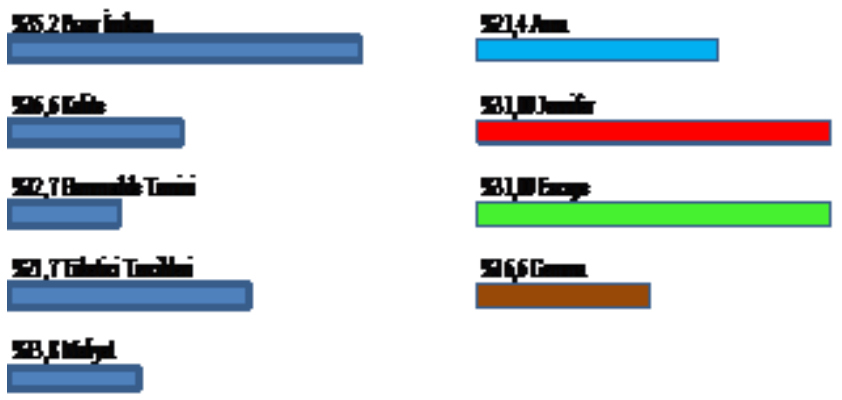

Şekil 5 incelendiğinde, Jennifer adlı kumaşın duyarlılık analiz sonuçlarına göre de üstün olduğu ve Jennifer adlı kumaşın tercih edileceği görülmektedir. Ancak Escape adlı kumaş da firma tarafından üretilmesi uygun olan kumaşlar içerisindedir. Escape ve Jennifer adlı iki kumaş değer bakımından birbirine yakın çıktığından aralarında çok yüksek derecede bir farklılık bulunmamaktadır. Eğer ki firma tek kumaş üretim açısından ele alınırsa; firmanın Jennifer adlı kumaşı üretmesi en uygun olmaktadır.

Ana kriterler içerisinde en önemli olan kriterpazar imkanı kriteri olarak belirlenmiştir. Pazar imkânına ilişkin duyarlılık grafiğine bakıldığında önemli alternatif olarak Escape adlı kumaş ön plana çıkmaktadır. Pazar imkânına ait duyarlılık grafiği Şekil 6'da gösterilmiştir.

Şekil 6. Ana Kriterler Açısından Önemli Olan Pazar İmkânına İlişkin Duyarlılık Grafiğgi

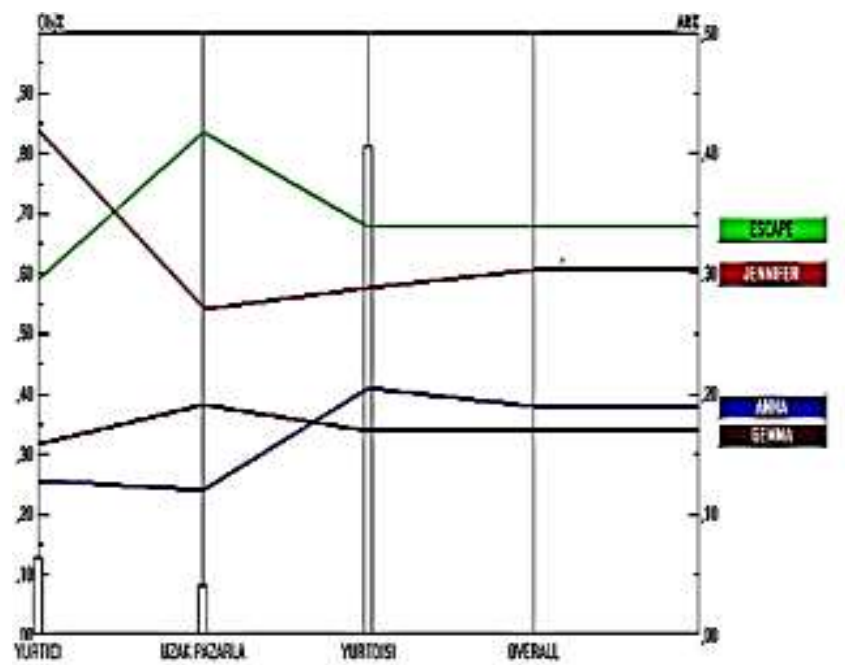

Şekil 6 incelendiğinde, Pazar imkanına ilişkin kriter bakımından Escape adlı kumaşın daha yüksek derecede öneme sahip olduğu görülmektedir. Hemen ardından Jennifer adlı kumaş gelmektedir. Ancak, her iki kumaşın önem bakımından birbirine yakın olduğu görülmektedir.

Pazar imkanına ilişkin kritere verilen ağırlık arttırılırsa Escape adlı kumaş alternatifinin öncelik kazanacağ gözlemlenmiştir. Bunun sebebi olarak en önemli kriter olan pazar imkanı açısından Escape adlı kumaşın daha büyük önceliğe sahip olması düşünülebilir. Pazar imkânına verilen önem derecesi \%55 ve yukarısına çıkarıldığında Escape adlı kumaş ön sıraya taşınmıştır. Bu durum Şekil 7' de gösterilmiştir. 
Şekil 7: Pazar İmkânına Verilen Önem Derecesinin Arttırılmasına İlişkin Gösterim

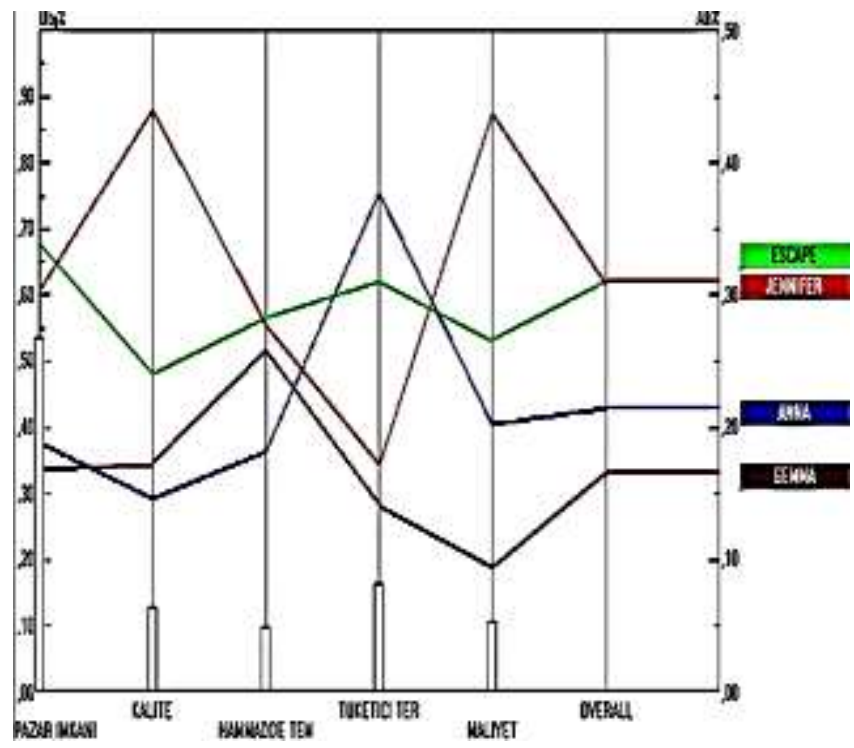

Eğer ki firma ikinci önemli kriter olan tüketici tercihlerine verilen önem derecesini arttırırsa yani \%30'lara çıkardığında seçimi en uygun kumaş olan Jennifer adlı kumaş yerini Escape adlı kumaşa bırakmaktadır. Escape adlı kumaş tüketici tercihlerine önem verildikçe üretilmesi en uygun kumaş olmaktadır. Hatta önem derecesi, \%50'lere kadar çıkartıldığında altlarda olan Anna adlı kumaş ikinci sıraya gelmektedir. Verilen önem tamamı ile arttırıldığında ise Anna kumaş üretilmesi en uygun kumaş olduğunu görülmektedir.

Anna türü kumaş Viskon ve örgülü bir kumaş türüdür. Örme türü kumaşlar kullanım kolaylığ bakımından genel anlamda tüketiciler tarafından daha çok tercih edilmektedir. Bununla ilgili firmada 100 kişiye "örme ve dokuma kumaş arasında seçim yapılması istense hangisi tercih sebebiniz olur?" diye sorulmuştur. Sonuçta, \%40 oranında bir çoğunluk tercihini örme kumaştan yana kullanmıştır. Bu durum çıkan sonucun doğruluğunu teyit etmektedir. Ayrıca, Anna adlı kumaşın örme özelliğinin yanı sıra viskon özelikte bir kumaş olduğu belirtilmişti. Kumaşlara viskon ve polyester olarak bakıldığından polyester kumaş, viskona göre daha çok tercih sebebi olmaktadır. Ancak polyester kumaş doğal bir kumaş değildir. Viskon polyester bir kumaştır ve pamuğa benzer bir kumaştır bu özellikleri sebebi ile de polyester kumaşa kıyasla daha pahalıdır. Sağlıklı olması sebebi ile tüketiciler bu kumaşı tercih etmek ister ancak fiyatı ve polyester kumaşın birkaç özelliği sebebi ile polyester kumaş günümüzde daha çok tercih sebebi olmaktadır. 100 kişiye sorulan örme ve dokuma arasındaki seçim sorusu, viskon ve polyester kumaş içinde işletme çalışanlarına yöneltildiğinde de çıkan sonuç \%60 civarında Viskon kumaşın tercih edileceğini ortaya koymuştur. Bunun sebebi ise polyester kumaşın petrol gibi kimyasallardan elde edilmesi, viskon kadar sağlıklı olmaması, doğal kumaşlar gibi nem alma özelliğinin olmaması vb. birçok nedenden dolayıdır. Diğer \%40'lık kısım ise fiyatından dolayı polyester kumaşı tercih edeceklerini belirtmiştir.

\section{Tartışma ve Sonuç}

Çalışmadan elde edilen sonuçlar genel olarak değerlendirildiğinde; Jennifer adlı kumaş ile Escape kumaşınbirbirine yakın olmasına rağmen az bir farkla üretimde tercih edilebilecek ilk kumaş Jennifer olarak belirlenmiştir. Escape ise 2. sıradayer almaktadır. Jennifer kumaşın üretim açısından uygun olmasının sebebi, bu tür kumaşın herhangi bir ön işleme tabi tutulmayıp dolayısıyla zaman açısından fayda sağlamasıdır. Ürünün teslim süresi diğer kumaşlara kıyasla daha kısa olduğu bilinmektedir. Bunun yanı sıra Jennifer kumaş; polyester dokuma kumaş olmasınedeniyle makinedeki işlem süreci de kısadır. Bu tür kumaş 4 Makinede işlem görürken diğer kumaşlar 12 makineye kadar işlem sürecine tabi olmaktadır. $\mathrm{Bu}$ tür işlemler kumaşı kalite bakımından da etkilemektedir.

Bütün kriterler açısından tek tek ele alınıp incelendiğinde; firma "Pazar imkanı" kriterini göz önüne alarak üretim yapmak isterse öncelik olarak üretmesi gereken kumaşın Escape olduğu belirlenmiştir. . Firma, "Kalite" kriteri bakımından üretim yapmak isterse; Jennifer adlı kumaşın üretimine ağırlı vermesi gerektiği sonucu ortaya çıkmaktadır.

Firma "Hammadde Temini" kriterini ele alarak üretim yapmak isterse, Escape adlı kumaş türünün üretimine ağırlık vermesi gerekmektedir. Eğer,firma “Tüketici Tercihleri" açısından ele alıp üretim yapmak isterse, Anna adlı kumaş türüne ağırlık vererek üretim yapması gerekmektedir.

Anna adlı kumaşın tüketiciler tarafindan tercih edilme sebebi viskon türü bir kumaş olmasındandır. Viskon kumaş; zarif, hoş ve nem alma özellik bakımından pamuktan daha yüksek bir kumaş olma özelliği ile tüketiciler tarafindan fazla tercih edilen kumaş çeşididir. Bu kumaştan üretilen kıyafetler rahatsızlık vermeyen ten ile uyumlu kumaşlardır. $\mathrm{Bu}$ nedenlebu tür kumaşın giyimi rahat ve kolaydır. Gömlek, tişört, astar, iç çamaşır yapımında tercih edilen kumaşlardır. Ayrıca firmanın çalıştığı müşteriler dikkate alındığında bu kumaş türünden yoğun şekilde talep olması tüketici tercih kriterinde bu kumaşın ilk sırayı almasına neden olmaktadır. Firmadan elde edilen bilgiye göre 2018 y1lı içerisinde firma bu kumaş türünden 780.802 metre kumaş üretip satmıştır.

Firma "Maliyet" kriteri açısından ele alınıp üretim yapmak isterse Jennifer adlı kumaş çeşidine üretimde ağrılık vermesi gerektiği söylenebilir. Jennifer kumaş polyester dokuma türü bir kumaştır. Polyester kumaş herhangi bir ön işleme tabi değildir. Ham olarak alınan kumaşı doğrudan üretime sokulup baskı ve desen işlemleri yapılabilir. $\mathrm{Bu}$ yönü ile kumaşın ön işleme tabi tutulmadan direkt boyamaya sokulması maliyet açısından ele alındığında üretilmesi en uygun kumaş çeşidi olarak ortaya çıkmaktadır.

Ele alınan çalışma, firmaların çalışma politikaları ve gelecek planları hakkında bilgi edinmemize imkân tanımaktadır. Çalışmadan elde edilen sonuçlar, bu firmanın tüketici tercihlerini dikkate aldığını, sipariş bazlı üretimi yoğunlukla çalıştığı söylenebilir. $\mathrm{Bu}$ da diğer firmalar açısından bakıldığında, firmanın müşterilerin taleplerine uygun üretim yaptığını müşteri isteklerini dikkate aldığını ortaya koymaktadır. Yurtiçi literatür incelendiğinde, tekstil 
alanında AHP yöntemi ve bir seçim kararı ile ilgili daha önce yapılmış çok fazla çalışmaya rastlanılmamıştır. Yapılan çalışmalar genellikle, tedarikçi seçimi, en iyi okul seçimi, personel seçimi konusunda karar verme, iş tercihinde karar verme vb. konulara ilişkindir.

Literatürde az da olsa ele alınan çalışma ile benzer ya da farkl11ık gösteren sonuçlara ulaşmak mümkündür. Güleş vd.(2014) çalışmasındaele alınan kriterler arasında maliyet ve kalite kriterleri öne çıkmıştır. Bu iki kriter firmalar açısından önem arz ettiğinden Aydın'ın (2006) çalışmasında da ele alındığı ve önem teşkil ettiği görülmektedir. Kalite, firmaların sürekliliğini sağlaması açısından ve müşteri memnuniyeti açısından yalnızca tekstil sektöründe değil birçok sektörde de en önemli faktör olarak değerlendirilmektedir. Firmaların kaliteli üretim yapmasının yanı sıra, aynı zamanda yapılan ürünü minimum maliyetle elde etmesi de firmaların devamlılığ açısından önemlidir.

AHP yöntemi ile yapılan bu çalışma, Çerkezköy ve diğer Organize Sanayi bölgeleri açısından birçok üretim sektörüne yol gösterici bir rol üstlenebileceği değerlendirilmektedir. Ancak, sonuçların tam anlamıyla firmanın üretim yapacağı ürün hakkında kesin bilgi verdiğini söylemek, karar vericilerin etkisinedeniyle mümkün değildir. $\mathrm{Bu}$ sonuçlar çerçevesinde farklı sanayi bölgelerinde tekstil işletmeleri için de bu yönteme başvurarak, en uygun kumaş üretimi, üretim planları, personel seçimleri gibi konularda araştırmalar yapılabilir.

\section{Kaynakça}

Akyıldız, E. (2006) Analitik Hiyerarşi Süreci Ve Bankacılık Sektöründe Bir Uygulama (Yüksek Lisans Tezi). Gazi Üniversitesi Sosyal Bilimler Enstitüsü, Ekonometri Anabilim Dalı, Ankara.

Aydın, S. (2006). Tutundurma Karması Elemanlarının Analitik Hiyerarşi Süreci Ile Değerlendirilmesi: Türk Ev Tekstili Sektöründe Bir Uygulama.(Yüksek Lisans Tezi). Osmangazi Üniversitesi Sosyal Bilimler Enstitüsü, Eskişehir.

Aytürk, S. (2006). Askeri Savunma Sistemlerinde Analitik Hiyerarşi Ve Analitik Şebeke Prosesi Ile Hafif Makineli Tüfek Seçimi (Yüksek Lisans Tezi). Gazi Üniversitesi Fen Bilimleri Enstitüsü, Ankara.

Banwet, D.K. \&Majumdar, A. (2014). Comparativeanalysis of AHP-TOPSIS and GA-TOPSIS methodsforselection of rawmaterials in textileindustries. Proceedings of the 2014 International Conference on IndustrialEngineeringand Operations Management Bali, Indonesia, January 7 - 9, 20712080.

Başkaya, Z.,\& Akar, C. (2005). Üretim Alternatifi Seçiminde Analitik Hiyerarşi Süreci: Tekstil İşletmesi Örneği. Sosyal Bilimler Dergisi,(1), 273:286.

Çakıroğlu, L. (2015). Özgün Baskı ve Tekstil Uygulamaları. (Yüksek Lisans Tezi). Haliç Üniversitesi Sosyal Bilimler Enstitüsü, İstanbul.

Dağdeviren, M. (2002). Analitik Hiyerarşi prosesi ile yeni bir analitik iş değerlendirme tekniğinin
Geliștirilmesi.(Yayınlanmamış Yüksek Lisans Tezi). Gazi Üniversitesi Fen Bilimleri Enstitüsü, Ankara.

Ekti, E. (2013). Tekstil Sektörü Raporu Sektörel Raporlar Serisi. T.C Doğu Marmara Kalkınma Ajansı Düzce Yatırım Destek Ofisi.

Gemci, H.F. (2007). Türkiye'de Tekstil Piyasası ve Dünyadaki Yeri.(Yüksek Lisans Tezi). Kadir Has Üniversitesi Sosyal Bilimler Enstitüsü, İstanbul.

Güner, M. (2003). Analitik Hiyerarşi Yönteminin Fason İşletme Seçiminde Kullanılması: Tekstil ve Konfeksiyon. Ege Üniversitesi Tekstil Müh. Bölümü Dergisi (4), 1-6.

Güleş, H.K.,Çağliyan , V., \& Şener, T. (2014). Hazır Giyim Sektöründe Analitik Hiyerarşi Prosesi Yöntemine Dayalı Tedarikçi Seçimi. Selçuk Üniversitesi Sosyal Bilimler Enstitüsü DergisiÖzel Sayıs, 159-170.

Kuruüzüm, A.,\& Atsan, N. (2001). Analitik Hiyerarşi Yöntemi ve İşletmecilik Alanındaki Uygulamaları. Akdeniz Üniversitesi İ̈BF Dergisi (1), 83-105.

Saaty, T.L. (1982). DecisionMakingForLeaders.Lifetine Learning Publications, California.

Sasil, J.C.,\&Digalwar, A.K.(2015). Application of AHP and TOPSIS MethodforSupplierSelectionBetweenIndia\&China in TextileIndustry.International ResearchJournal of EngineeringandTechnology, 2 (4), 1730-1738.

Timor, M. (2011). Analitik Hiyerarşi Prosesi. Türkmen Kitapevi, İstanbul.

Tong,O.,Shao, S., Zhang, Y., Chen, Y., Liu, S. Zhang, S.S.(2012). An AHP-based water-conservation and waste-reduction indicator system for cleaner production of textile-printing industry in China and technique integration. Clean Technologies and Environmental Policy, 14(5), 857-868.

Özek, V.B. (2014). Söyleşi: Pamuk ve Diğer Elyaflar. Bossa T.A.Ş. Satın alma Müdürü.

Özdemir, M. S.,\&Saaty, T. L. (2006). TheUnknown in DecisionMakingWhatto Do AboutIt. EuropeanJournal of OperationalReserarch, 174 (1), 349-359

Yaralıŏlu, K. (2001). Performans değerlendirmede Analitik Hiyerarşi Prosesi. Dokuz Eylül Üniversitesi İktisadi İdari Bilimler Fakültesi Dergisi, 16(1), 129142.

Yetim S. (2004). Tek değişkenli reel değerli fonksiyonlarda türev kavramına etki eden bazı matematik kavramlarının analitik hiyerarşi prosesi ile analizi. Gazi Üniversitesi Kastamonu Eğitim Dergisi, 12(1), 137-156.

Yilankiran, N. (2006). Investigation Of TheNonwovenFabricProduction Technologies and a Cost-benefitanalysisfortheusage of medicalTextiles. (Yüksek Lisans tezi). Gaziantep Üniveristesi Fen Bilimleri Enstitüsü. 
Yılmaz, N. (2015). Türkiye'de tekstil sektöründe dağıtım kanalı seçiminde karşılaşllan problemler ve Adıyamanda Tekstil firmalarl üzerine bir
uygulama.(Yüksek Lisans Tezi). Mehmet Akif Üniversitesi Sosyal Bilimler Enstitüsü, Burdur. 